\title{
Experimental investigation on breaching of embankments
}

\author{
ZHU YongHui ${ }^{1,2 *}$, VISSER P J ${ }^{3}$, VRIJLING J K ${ }^{3}$, WANG GuangQian ${ }^{1}$ \\ ${ }^{1}$ State Key Laboratory of Hydroscience and Engineering, Tsinghua University, Beijing 100084, China; \\ ${ }^{2}$ Changjiang River Scientific Research Institute, Changjiang Water Resources Commission, Wuhan 430010, China; \\ ${ }^{3}$ Faculty of Civil Engineering and Geosciences, Delft University of Technology, Delft, 2600 GA, Netherlands
}

Received August 6, 2010; accepted November 10, 2010

\begin{abstract}
Breaching of embankments has recently drawn more and more attention due to its importance in the development of early warning systems for embankment failures, in the evacuation plans of people at risk, in the design method of embankments based on a risk-approach, etc. The erosion process observed during embankment breaching tests in the laboratory and the analysis of the results are described in this paper. Five embankments, one constructed with pure sand, four with different sand-silt-clay mixtures were tested. The height of the embankments was $75 \mathrm{~cm}$ and the width at the crest was $60 \mathrm{~cm}$. Examination of the data from these tests indicated that headcut erosion played an important role in the process of breach growth in the embankments made of cohesive soil mixtures. Flow shear erosion, fluidization of the headcut slope surface, undermining of the headcut due to impinging jet scour and discrete soil mechanical slope mass failure from the headcut were all observed during these tests. For the embankment constructed with pure sand, the breach erosion process was dominated by shear erosion, which led to a gradual and relatively uniform retreat of the downstream slope. The cohesive proportion in the sand-silt-clay mixtures strongly slowed down the erosion process.
\end{abstract}

embankments, breaching, experiments, headcut, erosion

Citation: Zhu Y H, VISSER P.J., VRIJLING J.K, et al. Experimental investigation on breaching of embankments. Sci China Tech Sci, 2011, 54: 148-155, doi: $10.1007 / \mathrm{s} 11431-010-4208-9$

\section{Introduction}

Embankments, including both earth dams and (river and sea) dikes, are of large benefit to people worldwide. Currently there are about 45000 dams higher than $15 \mathrm{~m}$ throughout the world, of which about $73 \%$ were built in the last 50 years. These dams and their reservoirs provide benefits in water supply, irrigation for agriculture, flood control, hydropower, inland navigation, recreation and so on [1]. For the world well- known lowlands, the Netherlands has many kilometers of dikes to protect the lowland against flooding from either sea or rivers. In the absence of dikes and dunes more than $65 \%$ of the country would be flooded at high sea and high

\footnotetext{
*Corresponding author (email: yhzhu75@yahoo.com)
}

river levels [2].

Nevertheless, devastating disasters can occur if an embankment fails. In February 1953 in the Netherlands, dike breaches in about 900 places due to heavy storm surge led to one of the biggest natural disasters in the Dutch history: 1835 people lost their lives and a direct economic loss of about $14 \%$ of the Dutch GDP was caused [3]. In 1889, overtopping of the South Fork Dam, Pennsylvania, USA, caused over 2200 deaths and large property losses [4]. In August 1975, the uncommonly heavy rainstorms (maximum 6-hour rainfall $830 \mathrm{~mm}$ ) in central China caused disastrous failures of the Banqiao Reservoir Dam and the Shimantan Reservoir Dam with 26000 deaths [5]. Therefore, understanding the physics of breach growth in embankments and modeling the breach development process is of significant importance to the development of early warning systems for 
embankment failures, to the evacuation plans of people at risk, to the design method of embankments based on a risk-approach, etc.

Various experiments on the breaching of embankments have been conducted during the last several decades [6]. These experiments include both large-scale tests in the field [7-13] and small-scale tests in the laboratory[14-22].The small-scale tests in the laboratory include numerous flume and wave basin experiments. Nevertheless, the breach formation and development in embankments is such a complicated process with various influencing factors involved in, such as profile and structure of embankment, type of foundation (erodible or non-erodible), type of material (cohesive or non-cohesive, and erosion of cohesive soil is already a very intricate phenomenon [23]), and causes of failures (overtopping, piping, slope sliding, etc.) that despite the many experiments conducted and the insight gained, our understanding of the embankment breaching mechanism is still unsatisfactory.

In the last fifty years, particularly since the 1980's, many mathematical models have been developed for the simulation of breach growth in embankments [17, 24-29]. The calibration and validation of most of these models remain, however, problematic due to the lack of good empirical data.

In order to improve the knowledge of the process of em- bankment breaching and to collect data for the calibration and validation of embankment breaching mathematical models, five laboratory tests were conducted at Delft University of Technology (DUT) in the Netherlands. This paper summarizes the results from these tests.

\section{Experimental set-up}

\subsection{Layout of the flumes}

The tests were conducted in a straight flume $35.5 \mathrm{~m}$ long, $0.8 \mathrm{~m}$ wide and $0.85 \mathrm{~m}$ deep (see Flume 1 in Figure 1). Another straight flume (Flume 2 in Figure 1), $27.0 \mathrm{~m}$ long, 2.0 $\mathrm{m}$ wide and $0.4 \mathrm{~m}$ deep was used as a "storage basin" for water recirculation during the experiments; this flume had a sediment trap at one end and a water inlet at the other end.

Due to the limited width of Flume 1, the tests focused on the first three stages of the five-step breach erosion process in embankments [17, 30], in which the breach develops mainly vertically with only ignorable widening. A vertical wooden wall was placed in the middle of Flume 1 to narrow the length of the embankment section to $40.0 \mathrm{~cm}$. Another vertical wooden wall was constructed perpendicularly to the middle wall to separate the upstream from the downstream, see Figure 1.

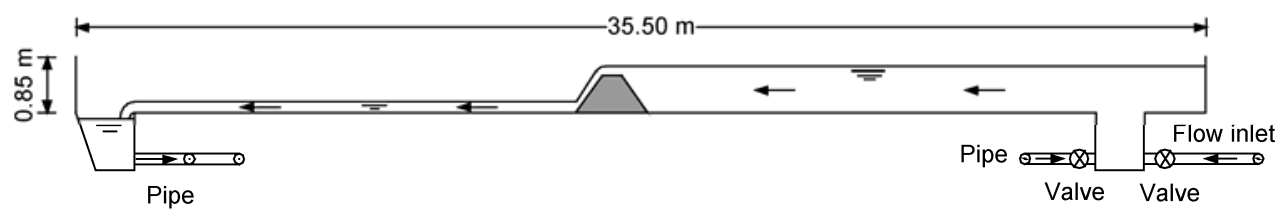

A-A: Longitudinal section of Flume 1

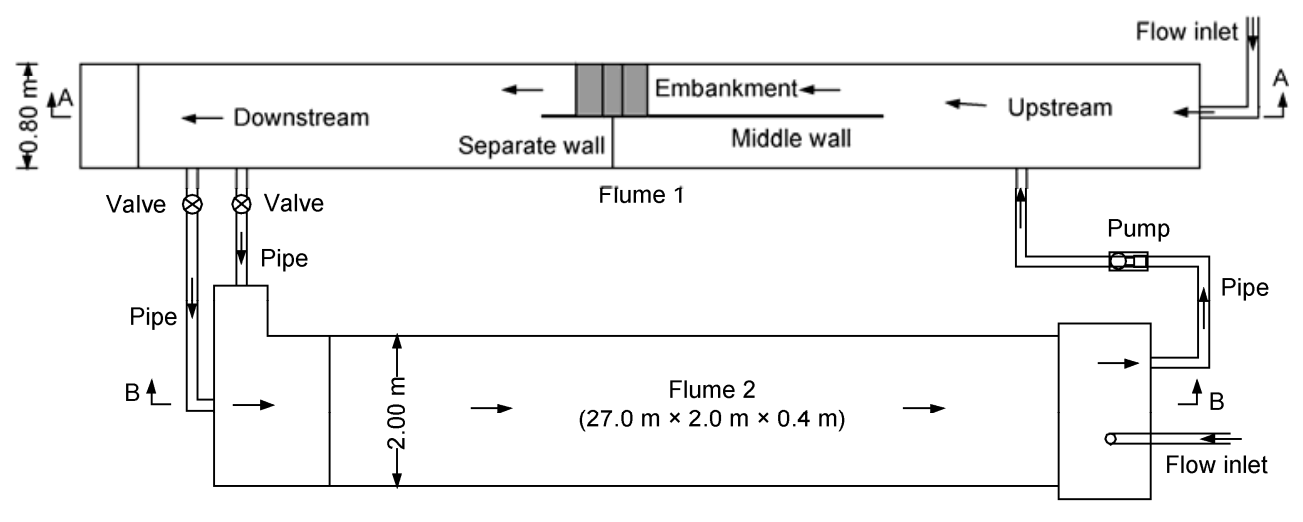

Top view of Flume 1 and Flume 2

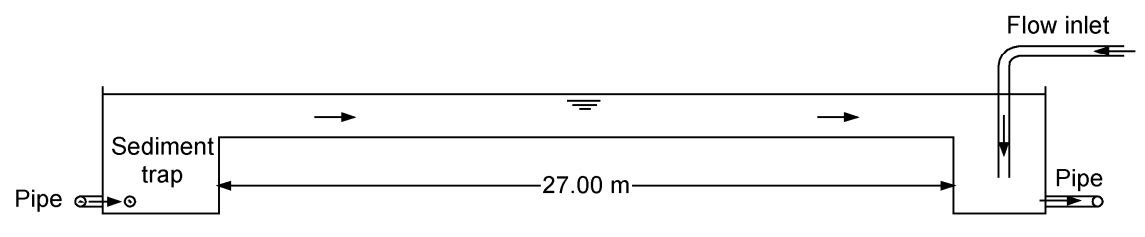

B-B: Longitudinal section of Flume 2

Figure 1 Sketch of the two flumes in the experiments. 


\subsection{Experimental program}

Altogether five tests were conducted, one with an embankment constructed with sand (test $\mathrm{T}_{\mathrm{s}}$ ), four with embankments constructed with different mixtures of sand, silt and clay (tests $T_{1}, T_{2}, T_{3}$ and $T_{4}$ ). Much attention was paid to get a proper sand-silt-clay mixture. A series of tests were carried out to measure the properties of the soil. Soil wet density $\left(\rho_{\mathrm{s}}\right)$ and water content $(\omega)$ were determined for each compacted layer of the embankment during embankment construction. Soil particle size distribution was determined by sieve analysis and sedigraph analysis. The pycnometer was applied to measure the soil particle specific density $\left(G_{\mathrm{s}}\right)$. Soil optimum water content $\left(\omega_{\text {opt }}\right)$ and maximum dry density $\left(\rho_{\mathrm{dm}}\right)$ were determined by proctor compaction tests for test $\mathrm{T}_{1}$. Soil unconfined compression tests were run by use of triaxial test apparatus to measure the undrained shear strength $\left(c_{\mathrm{u}}\right)$ for each of the four embankment tests with sand-silt-clay mixtures. Figure 2 shows the particle size distributions of the sand (for test $\mathrm{T}_{\mathrm{s}}$ ) and the sand-silt-clay soil mixtures (for tests $\mathrm{T}_{1}, \mathrm{~T}_{2}, \mathrm{~T}_{3}$ and $\mathrm{T}_{4}$ ). Table 1 summarizes the results of those soil property tests.

All the five tests had the same embankment configuration and dimensions, as summarized in Table 2 and shown in Figure 3. The height of the embankment was set as high as the flume permitted to allow observation of the embank-

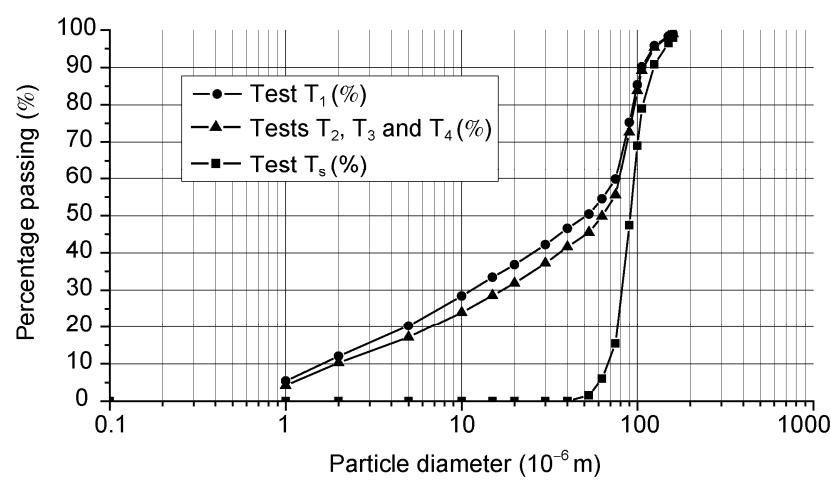

Figure 2 Soil particle size distributions.

Table 1 Summary of soil properties

\begin{tabular}{cccccc}
\hline Item & $\mathrm{T}_{\mathrm{s}}$ & $\mathrm{T}_{1}$ & $\mathrm{~T}_{2}$ & $\mathrm{~T}_{3}$ & $\mathrm{~T}_{4}$ \\
\hline$G_{\mathrm{s}}$ & 2.66 & 2.67 & 2.67 & 2.67 & 2.67 \\
$\rho_{\mathrm{s}}\left(\mathrm{kg} / \mathrm{m}^{3}\right)$ & 1650 & 1938 & 1936 & 1951 & 1948 \\
$\omega(\%)$ & 20.1 & 17.6 & 16.7 & 16.7 & 15.4 \\
$c_{\mathrm{u}}(\mathrm{kPa})$ & & 22.10 & 24.63 & 26.42 & 26.75 \\
$\omega_{\mathrm{opt}}(\%)$ & & 11.5 & & & \\
$\rho_{\mathrm{dm}}\left(\mathrm{kg} / \mathrm{m}^{3}\right)$ & & 1940 & & & \\
Void ratio & 0.94 & 0.62 & 0.61 & 0.60 & 0.58 \\
Degree of saturation $(\%)$ & 57.1 & 75.8 & 73.2 & 74.7 & 70.7 \\
Sand $(>50 \mu \mathrm{m})$ & 99.0 & 50.5 & 54.6 & 54.6 & 54.6 \\
Silt $(>2 \mu \mathrm{m})$ & 1.0 & 37.5 & 35.1 & 35.1 & 35.1 \\
Clay $(<2 \mu \mathrm{m})$ & 0.0 & 12.0 & 10.3 & 10.3 & 10.3 \\
Composition $(\%) \quad$ & & & & & \\
Median particle diameter $D_{50}(\mu \mathrm{m})$ & 91 & 53 & 63 & 63 & 63 \\
\hline & & & & &
\end{tabular}

Table 2 Embankment dimensions and configurations

\begin{tabular}{cc}
\hline Parameter & Value \\
\hline Embankment height & $75.0 \mathrm{~cm}$ \\
Embankment crest length & $40.0 \mathrm{~cm}$ \\
Embankment crest width & $60.0 \mathrm{~cm}$ \\
Embankment inner slope & $1: 2.0$ \\
Embankment outer slope & $1: 2.0$ \\
Thickness of soil foundation & $0.0 \mathrm{~cm}$ \\
\hline
\end{tabular}

Figure 3 Cross-section of the tested embankments.

ment breach erosion process as clear as possible under the given flume conditions.

\subsection{Experimental procedure}

The embankment was constructed in the flume by placing soil in horizontal loose lift layers about $0.10 \mathrm{~m}$ thick (except $0.20 \mathrm{~m}$ for test $\mathrm{T}_{\mathrm{s}}$ ). A hand-operated compaction roller was used to compact each loose layer. Special attention was paid to the compaction of soil against the two sidewalls. Before starting the embankment construction, a soil fill test was performed to establish a relationship between the number of passes $\left(N_{\mathrm{p}}\right)$ of the roller and the achieved soil dry density. Except test $\mathrm{T}_{1}$ in which $N_{\mathrm{p}}=4$, for all the other tests, including test $\mathrm{T}_{\mathrm{s}}, N_{\mathrm{p}}=2$ was applied. After the embankment was built, careful trimming of the embankment was done in accordance with the designed embankment profile.

The water levels both upstream and downstream the embankment were measured with four wave height meters, see G14, G15, G16 and G17 in Figures 4 and 5. Flow velocities in the flume axis and transverse directions were measured with three electromagnetic velocity sensors (EMSs, see E7, E10 and E11 in Figures 4 and 5). The process of breach growth was videotaped with two digital video cameras (VC1 and VC2 in Figures 4 and 5) and photographed with two digital cameras (DC1 and DC2 in Figures 4 and 5) placed at one side of the flume, except DC2 above the flume at the downstream side of the embankment. To facilitate reading of the development of the embankment profile from the recorded pictures and videos, horizontal and vertical lines were drawn on the glass sidewall of the flume at mutual distances of $10 \mathrm{~cm}$.

Before starting the test, water was first pumped into the "storage basin" Flume 2, and then the upstream section of Flume 1 was also filled through the water inlet. A suitable wood board and a suitable sandbag were cautiously placed on the embankment crest to prevent water from overflowing 


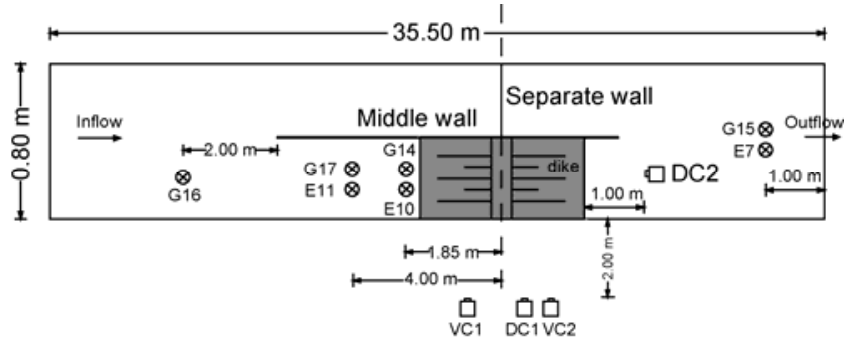

Figure 4 Top view of experimental apparatus in the flume (drawing not to scale).

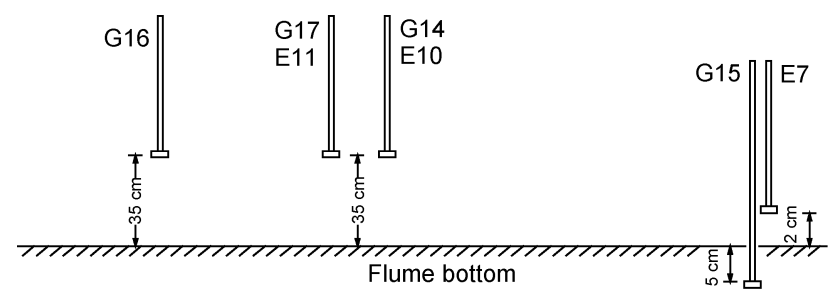

Figure 5 Vertical positions of experimental apparatus in the flume (drawing not to scale).

the embankment before the upstream water level had risen to a certain height (normally $5.0 \mathrm{~cm}$ above the embankment crest). Whereafter the wood block and sandbag were taken away quickly to start the embankment breaching process. From then on, water was recirculated by pump and pipes (see Figure 1).

\section{Results and discussions}

Water levels and flow velocities were measured during all the tests. Figure 6 shows the results of water level measurement of G17 and flow velocity measurement of E11 for test $T_{2}$, and Figure 7 the results of water level measurement of G14 and flow velocity measurement of E10 for test $\mathrm{T}_{4}\left(u_{x}\right.$ and $u_{y}$ indicate the flow velocities measured in the flume axis direction and transverse direction, respectively).

Evolution of the embankment profile was determined from the videos and photographs. For tests $T_{1}, T_{2}, T_{3}$ and $T_{4}$ (i.e. the tests with sand-silt-clay mixtures), it was observed that erosion usually occurred first at locations close to the toe of the embankment when the embankment was overflowed (except for test $\mathrm{T}_{4}$ ). Soon this erosion extended to the entire slope, with a larger erosion rate occurring at the lower part of the slope than at the upper part, inducing a steepening of the slope in time (see e.g. Figures 8, 9, 10 and 11). Besides the toe of the embankment, the transition area between the embankment crest and the downstream slope was the second place susceptible to earlier and faster erosion. Erosion at the embankment crest was relatively slow, depending mainly on the erosion resistance of the soil material. However, this erosion lowered the height of the embankment and increased the breach flow rate in time, which

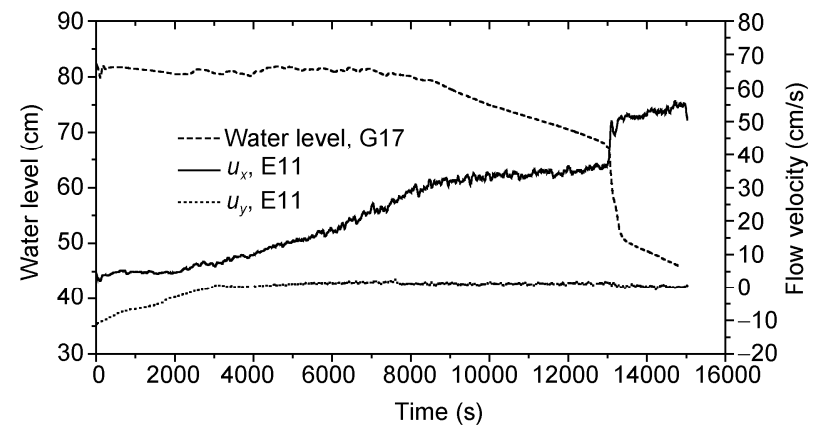

Figure 6 Results of water level measurement of G17 and flow velocity measurement of E11 for test $\mathrm{T}_{2}$.

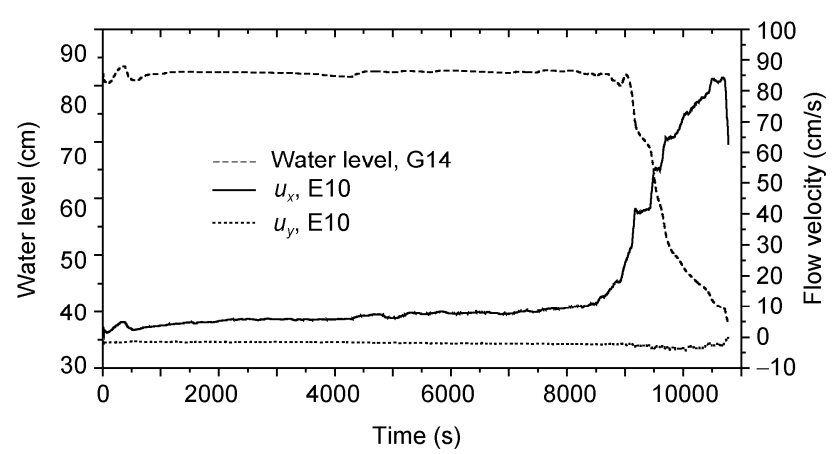

Figure 7 Results of water level measurement of G14 and flow velocity measurement of E10 for test $\mathrm{T}_{4}$.

in turn accelerated the breach erosion process.

The steepened downstream slope of the embankment evolved gradually into a headcut (a headcut here means a vertical or near vertical drop or discontinuity on the flowbed; see Figure 12). Then, instead of flowing down attaching to the headcut slope, the breach flow impinged like a jet onto the downstream flume bottom, imposing considerable erosive forces on the toe of the slope (see Figure 13). Strong scour of the toe of the slope (i.e. headcut undermining) due to the jet impingement was observed in all the four tests with sand-silt-clay mixtures. This undermining generally resulted in a reverse slope at the lower part of the headcut (see e.g. Figures 8, 9 and 10). It was observed that when the breach flow rate was very large, the action point of the jet flow on the flume bottom was relatively far away from the toe of the headcut. Under the circumstances of flat and non-erodible headcut foundation as in the present tests (i.e. the flat steel bottom of the flume), the portion of flow reflecting towards the headcut was relatively small and therefore the headcut undermining actually was somewhat slower compared with a smaller flow rate situation. However, the erosion occurring at the top of the headcut was faster with a larger flow rate. In case of an erodible embankment foundation, a scour hole would be expected to form in the foundation. It enlarged in time, both vertically and towards the headcut, undermining the headcut slope.

Fluidization and consequent failure of the headcut sur- 


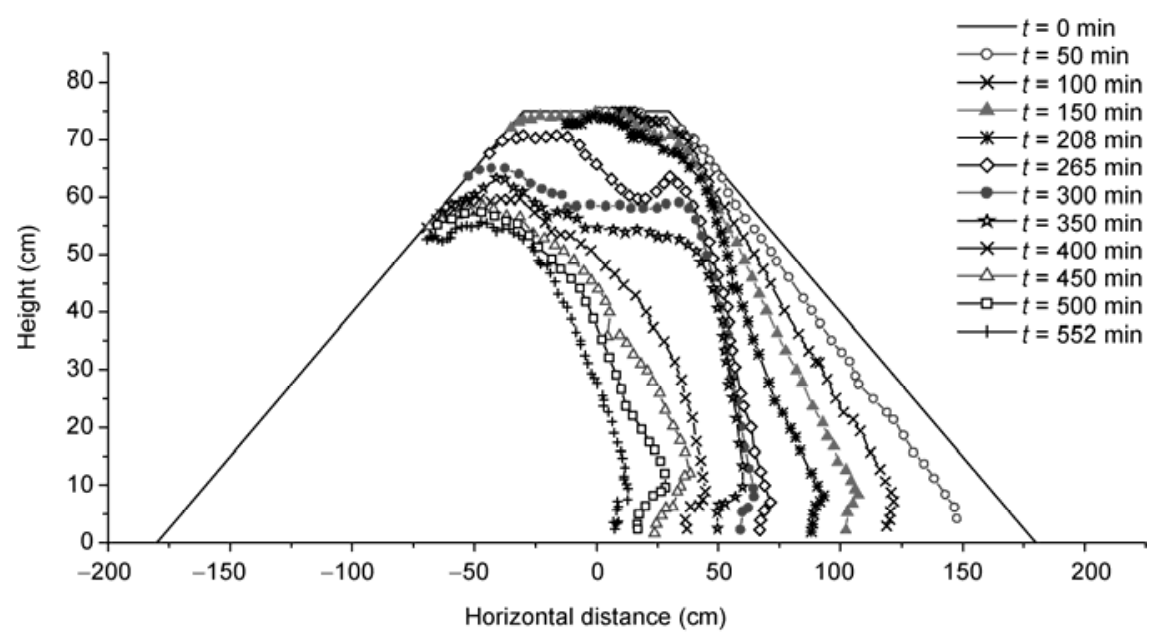

Figure 8 Embankment profile development of test $T_{1}$.

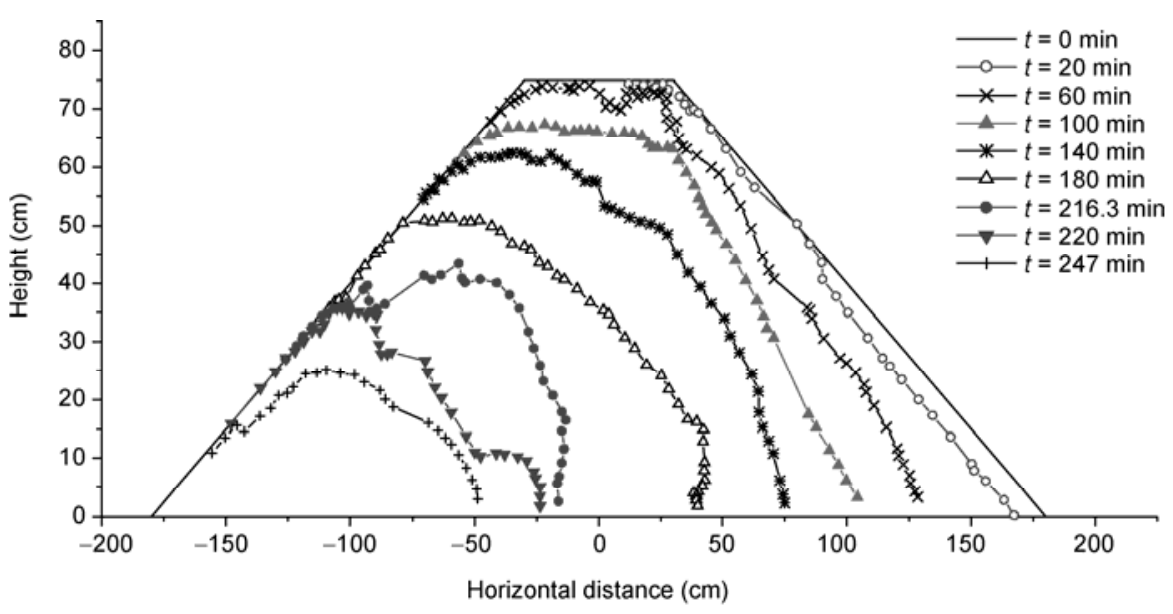

Figure 9 Embankment profile development of test $\mathrm{T}_{2}$.

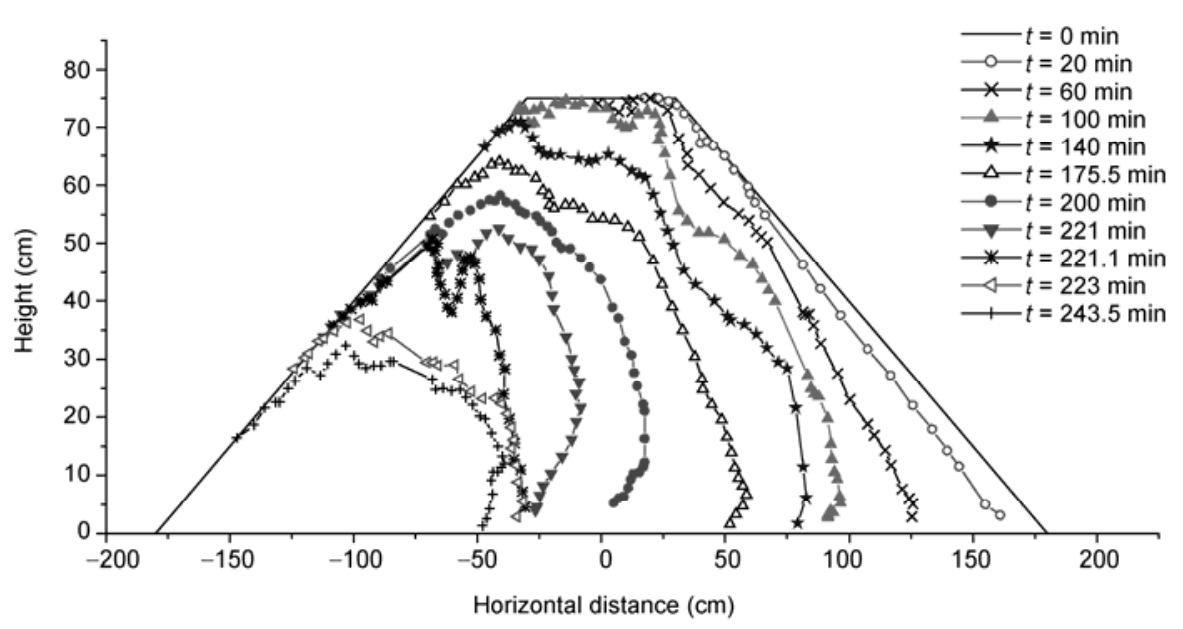

Figure 10 Embankment profile development of test $\mathrm{T}_{3}$.

face layer due to the diffused falling water was also observed during the tests. This effect speeded up the retreat of the headcut and accordingly the overall rate of embankment breaching. However, this process was very dynamic and irregular and therefore quantification of it was very diffi- cult.

During all the four tests with cohesive soil mixtures (i.e. tests $T_{1}, T_{2}, T_{3}$ and $T_{4}$ ), soil mechanical slope mass failure occurred discretely from the headcut, however, not very frequently. Yet, when this slope mass failure occurred, the 


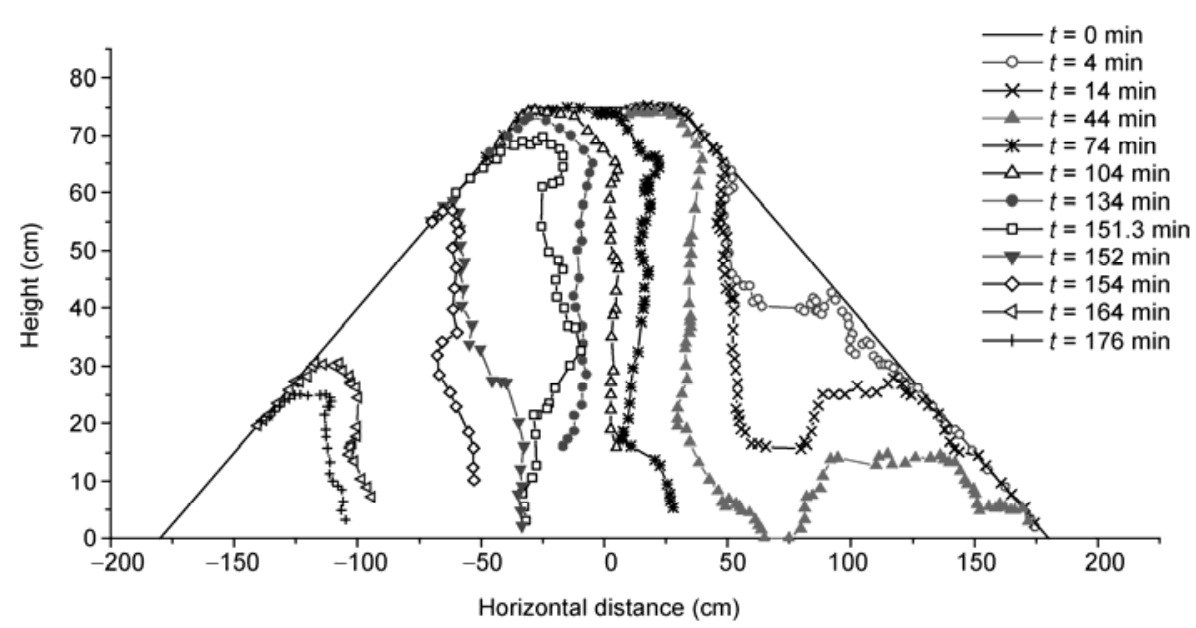

Figure 11 Embankment profile development of test $\mathrm{T}_{4}$.

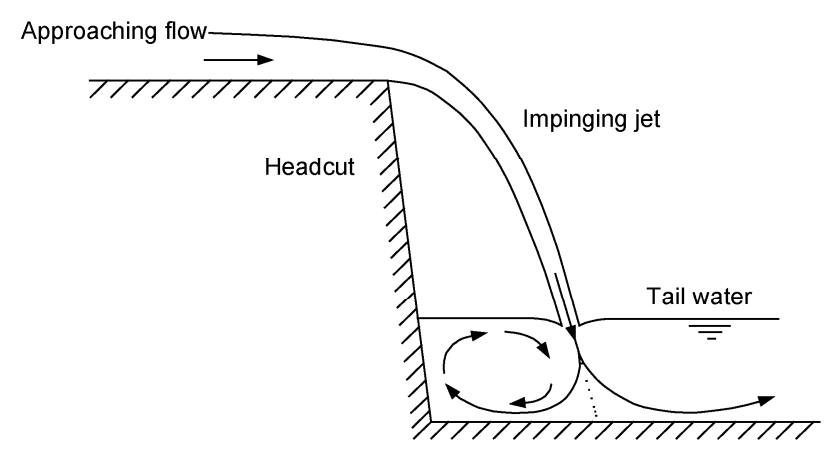

Figure 12 Sketch of a headcut.

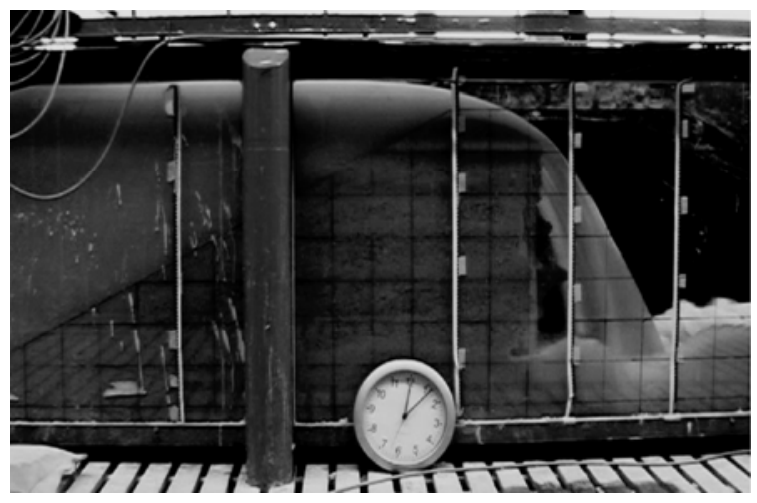

Figure 13 Headcut and breach flow jet impingement (test $\mathrm{T}_{4}$ ).

loss of soil from the headcut could be a very large chunk, followed by an instant increase of the breach flow. It was also noted that in many cases the occurrence of headcut slope mass failure was accompanied by appearance of $\operatorname{crack}(\mathrm{s})$ on the top of the headcut. This might indicate that consideration of the tensile stress in the soil is needed when dealing with cohesive embankment breach erosion, although in traditional soil mechanics theory soil tensile strength is often not taken into account.

For tests $T_{1}, T_{2}, T_{3}$ and $T_{4}$, the transition between the embankment crest and the downstream slope sometimes eroded into a rounded angle. Then the breach flow did not flee away from the downstream slope at the top, instead it rushed down along the slope and detached from the slope at a certain lower point and impinged towards the foundation with less strong scour potential.

For the sand-embankment test $\mathrm{T}_{\mathrm{s}}$, erosion was first observed to occur at the upper half of the downstream slope of the embankment, and then a bar was developed at the lower part of the slope (see Figure 14). The upper portion of the slope was steepened in time and a headcut was also formed, showing similar characteristics as the tests with sand-siltclay mixtures (which were not expected before the test). The mainstream of the breach flow also fled away from the headcut at the headcut brink, however, no large slope mass failure was observed from the headcut. The backward migration of the headcut was mainly due to the surface erosion from the slope. Later, when this erosion approached the upstream slope of the embankment, the gradient of the headcut became gentler and remained more or less constant thereafter, indicating more or less uniform erosion along the slope.

Comparing the time scale of the test with pure sand (i.e. test $\mathrm{T}_{\mathrm{s}}$ ) and the tests with sand-silt-clay mixtures (i.e. tests $\mathrm{T}_{1}, \mathrm{~T}_{2}, \mathrm{~T}_{3}$ and $\mathrm{T}_{4}$ ) shows that the influence of soil cohesiveness on the breach erosion process is very remarkable. Under the same embankment profile and similar hydraulic conditions, the whole duration of test $\mathrm{T}_{\mathrm{s}}$ lasted less than 3 minutes, which was very fast compared with the four tests with sand-silt-clay mixtures, as summarized in Table 3. This demonstrated that the cohesive portion in the soil mixtures strongly slowed down the erosion process. For test $T_{1}$, the factors (among others, if still any) contributing to the very long breaching duration definitely included its higher (although not much) clay proportion and the larger compaction applied. However, for test $\mathrm{T}_{4}$, unlike the other three tests with cohesive soil mixtures, the erosion initiated more or less in the middle of the downstream slope when it was overflowed, probably due to uneven compaction during 


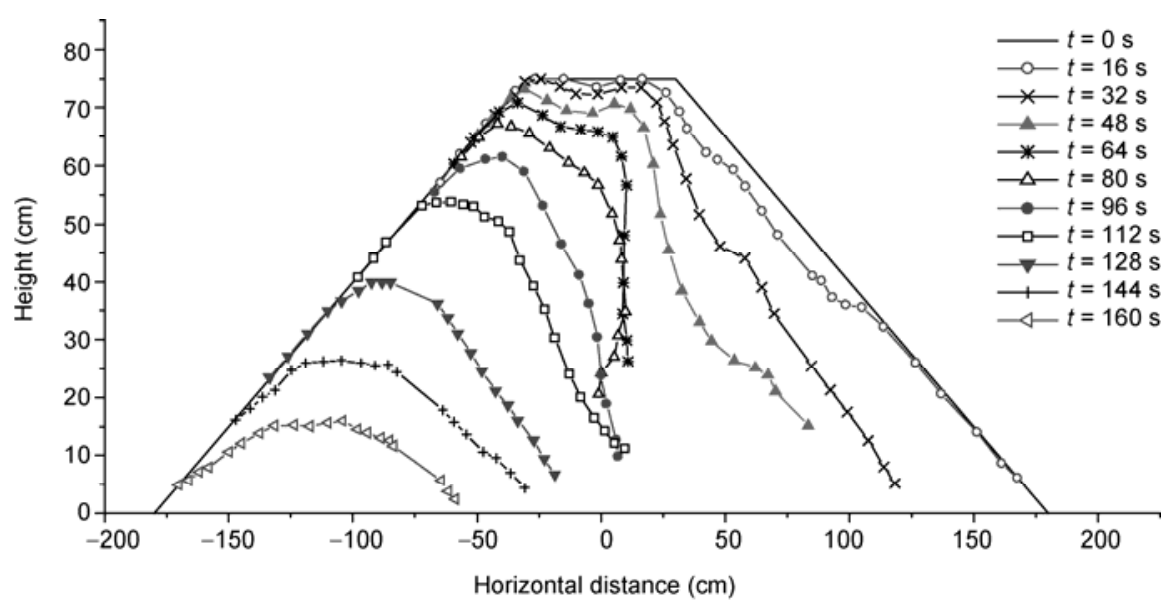

Figure 14 Embankment profile development of test Ts.

Table 3 Summary of durations of the five tests

\begin{tabular}{lccccc}
\hline & $\mathrm{T}_{\mathrm{s}}$ & $\mathrm{T}_{1}$ & $\mathrm{~T}_{2}$ & $\mathrm{~T}_{3}$ & $\mathrm{~T}_{4}$ \\
\hline Duration (min) & 2.7 & 553 & 247 & 245 & 178 \\
\hline
\end{tabular}

embankment construction, resulting in the formation of a headcut much sooner than expected and considerable speeding up of the breach erosion process.

During the embankment construction it was found that water content had an important influence on the performance of the sand-silt-clay soil mixtures. In general, when above the soil optimum water content, the higher the water content is, the harder it is to compact the soil to the desired soil density. In test $\mathrm{T}_{1} 4$ passes of the roller were applied to gain a soil density of $1938 \mathrm{~kg} / \mathrm{m}^{3}$, in contrast to test $T_{2}$ with just 2 passes to achieve $1936 \mathrm{~kg} / \mathrm{m}^{3}$ soil density, although there was only a minor difference $(0.9 \%)$ in their water contents $\left(17.6 \%\right.$ for test $\mathrm{T}_{1}$ and $16.7 \%$ for test $\left.\mathrm{T}_{2}\right)$. A larger water content also made the soil behave like a spring during the compaction, increasing the difficulties of compaction as experienced to a certain degree in test $\mathrm{T}_{1}$. For unsaturated soil, an increase of the water content generally leads to a decrease in the soil strength [31]. Nevertheless, in the present experiments this effect on the embankment breach erosion process was overshadowed by the influences of the compaction effort and the uneven compaction (for test $\mathrm{T}_{4}$ ).

\section{Conclusion}

Laboratory experiments on breaching of embankments were described in this paper. Five embankments, one made of pure sand, four of sand-silt-clay mixtures were tested. The embankments all had a height of $75.0 \mathrm{~cm}$ and a width of $60.0 \mathrm{~cm}$ at the crest. The inclination of both slopes was 1:2.

The tests confirmed that headcut erosion plays a very important role in the process of breach growth in embankments constructed with cohesive materials. Erosion usually initiates at locations close to the toe of the embankment when overflowed. After formation of the headcut, mainly the flow shear erosion, headcut undermining and soil mechanical slope mass failure contribute together to the breach development. In the test with pure sand, headcut was also formed, however, no large slope mass failure was observed from the headcut, and the backward migration of the headcut was mainly due to the surface erosion from the slope. Comparison of the testing durations between the five tests indicated that the cohesive portion in the sand-silt-clay soil mixtures strongly slowed down the erosion process. Further, the higher the clay proportion in the soil mixtures was, the lower erosion rate was induced.

Due to the large complexities involved in the breaching of embankments, understanding of the mechanism of embankment breaching so far is still unsatisfactory. Therefore, more experimental researches are significant for better understanding of the physics of embankment breach growth. It is also recommended that the scale effect in embankment breaching experiments should be always clearly recognized.

This work was supported by the National Basic Research Program ("973” Program) of China (Grant No. 2007CB714106), the Scientific Research Foundation for the Returned Overseas Chinese Scholars, Ministry of Human Resources and Social Security of China, the National Natural Science Foundation of China (Grant No. 51009012) and the Scientific Research Foundation for the Returned Overseas Chinese Scholars, State Education Ministry.

1 ICOLD. Benefits and Concerns about Dams-An Argumentaire, Committee on Public Awareness and Education, ICOLD, 1997

2 Van de Ven G P. Man-made Lowlands, History of Water Management and Land Reclamation in the Netherlands. Utrecht: Uitgeverij Matrijs, 1993

3 Huisman P, Cramer W, van Ee G, et al. Water in the Netherlands, Netherlands Hydrological Society. Netherlands: Delft, 1998

4 Singh V P, Scarlatos P D. Analysis of gradual earth-dam failure, J Hydraul Eng, 1988, 114(1): 21-42.

5 Pan J Z. Merits of Dams (in Chinese). Beijing: Tsinghua University Press, 2000

6 Zhu Y H, Visser P J, Vrijling J K. Review on embankment dam breach modeling. In: Wieland M, Ren Q, Tan J S Y (eds), New De- 
velopments in Dam Engineering. London: Taylor \& Francis Group, 2004. 1189-1196

7 Yu C Z. Several issues in dam-break model tests (in Chinese). J Hy draul Eng, 1982, (3): 41-46

8 Pan S, Loukola E. Chinese-Finnish Cooperative Research Work on Dam Break Hydrodynamics, National Board of Waters and the Environment. Finland: Helsinki, 1993

9 Visser P J, Kraak A W, Bakker W T, et al. A large-scale experiment on breaching in sand-dikes. In: Proc Coastal Dynamics'95. Poland: Gdansk, 1996. 583-594

10 Meadowcroft I C, Morris M W, Allsop N W H, et al. Tollesbury Managed Set Back Experiment: Breach Design and Construction, and Embankment Failure Experiment. HR Wallingford Report TR 5, Wallingford, UK, 1996

11 Hahn W, Hanson G J, Cook K R. Breach morphology observations of embankment overtopping tests. In: Proc 2000 Joint Conf Water Resources Engineering and Water Resources Planning and Management (CD-ROM). Minneapolis, USA, 2000

12 Höeg K., Lövoll A, Vaskinn K A. Stability and breaching of embankment dams: Field tests on $6 \mathrm{~m}$ high dams. Int J Hydropower Dams, 2004, 11(1): 88-92

13 Zhang J Y, Li Y, Xuan G X, et al. Overtopping breaching of cohesive homogeneous earth dam with different cohesive strengths. Sci China Ser E-Tech Sci, 2009, 52(10): 3024-3029

14 Powledge G R, Dodge R A. Overtopping of small dams an alterative for dam safety. In: Waldrop W R (ed), Hydraulics and Hydrology in the Small Computer Age. Proceedings of Specialty Conference. New York: ASCE, 1985. 1071-1076

15 Fujita Y, Tamura T. Enlargement of breaches in flood levees on alluvial plains. J Nat Disaster Sci, 1987, 9(1): 37-60

16 De Looff H, Steetzel H J, Kraak A W. Breach growth: Experiments and modeling. In: Proc 25th Int Conf Coastal Eng. Orlando, USA, 1997. 2746-2755

17 Visser P J. Breach Growth in Sand-Dikes. Dissertation of Doctoral Degree. Delft: Delft University of Technology. 1998

18 Tingsanchali T, Chinnarasri C. Numerical modeling of dam failure due to flow overtopping. Hydrol Sci J, 2001, 46(1): 113-130
19 Coleman S E, Andrews D P, Webby M G. Overtopping breaching of noncohesive homogeneous embankments. J Hydraul Eng, 2002, 128(9): 829-838

20 Rozov A L. Modeling of washout of dams. J Hydraul Res, 2003, 41(6): 565-577

21 Morris M W, Mohamed M A A M, Vaskinn K A. Breach formation: Field test and laboratory experiments. J Hydraul Res, 2007, 45(Extra Issue): $9-17$

22 Fujisawa K, Kobayashi A, Aoyama S. Theoretical description of embankment erosion owing to overflow. Geotechnique, 2009, 59(8): 661-671

23 Zhu Y H, Lu J Y, Liao H Z, et al. Research on cohesive sediment erosion by flow: An overview. Sci China Seri E-Tech Sci, 2008, 51(11): 2001-2012

24 Fread D L. BREACH: An Erosion Model for Earthen Dam Failures, National Weather Service (NWS) Report, NOAA, Silver Spring, Maryland, USA, 1988

25 Singh V P. Dam Breach Modeling Technology. Kluwer, Dordrecht, Netherlands, 1996

26 Mohamed M A A, Samuels P G, Morris M W. Improving the accuracy of prediction of breach formation through embankment dams and flood embankments. In: Bousmar \& Zech (eds), River Flow 2002, Swets \& Zeitlinger, Lisse, the Netherlands, 2002. 663-673

27 Wang Z G, Bowles D S. Three-dimensional non-cohesive earthen dam breach model. Part 1: Theory and methodology. Adv Water Res, 2006, 29(10): 1528-1545

28 Zhu Y H, Visser P J, Vrijling J K. A Model for breach erosion in clay-dikes. In: Sanchez-Arcilla, A. (ed), Coastal Dynamics 2005, Proc 5th Int Conf on Coastal Dynamics (CD-ROM). Barcelona, Spain, 2006

29 Wang G Q, Liu F, Fu X D, et al. Simulation of dam breach development for emergency treatment of the Tangjiashan Quake Lake in China. Sci China Ser E-Tech Sci, 2008, 51(Supp): 82-94

30 Zhu Y H, Visser P J, Vrijling J K. Breach erosion in clay-dikes. In: Proc. XXXI IAHR Congress. Seoul, Korea, 2005. 3808-3817

31 Fredlund D G, Rahardjo H. Soil Mechanics for Unsaturated Soils. New York: John Wiley \& Sons, 1993 